\title{
Analisis Wacana Kekerasan Seksual Terhadap Perempuan dalam Pemberitaan Republika Online
}

\author{
Nur Fajrah Safira, Achmad Herman, dan Raisa Alatas \\ Fakultas Ilmu Sosial dan Ilmu Politik, Universitas Tadulako \\ nurfajrah25@gmail.com
}

\begin{abstract}
Sexual violence against women is a form of inequality in power relations or gender inequality between women and men that occurs both in the domestic sphere and in the public sphere. The issue of sexual violence is not only an individual problem, but a global problem that requires many groups to take part in it, including the mass media. Therefore, in reporting on sexual violence, the mass media as the fourth estate must play a role in shaping the value of equality in society. This study was conducted to determine the construction of discourse on sexual violence against women in Republika Online (ROL) reporting. The researcher uses a discourse analysis model of Roger Fowler et al, who views language as a certain ideological practice to limit the audience's view of a reality by analyzing the dimensions of vocabulary and grammar. This study uses a qualitative approach to collect data by observing and documenting ten news stories about sexual violence against women in ROL for the period 23 November 2020 to 10 March 2021. The results show that ROL has not taken sides with women as victims. This is marked by the marginalization of the dominant position of women in reporting, both in terms of naming and describing incidents of sexual violence. This marginalization is reflected in the use of passive sentences, nominalization, euphemisms, naming not independent and all that, which will weaken the position of women in reporting.
\end{abstract}

Keywords: discourse analysis; sexual violence; woman; online media; Republika

\begin{abstract}
Abstrak
Kekerasan seksual terhadap perempuan merupakan bentuk ketimpangan relasi kuasa atau ketidakadilan gender antar perempuan dan laki-laki yang terjadi di dalam ranah domestik maupun di dalam ranah publik. Isu kekerasan seksual tidak hanya menjadi persoalan individu, tapi persoalan global yang menuntut banyak golongan ikut andil di dalamnya, termasuk media massa. Oleh karena itu, di dalam membuat pemberitaan mengenai kekerasan seksual, media massa sebagai the fourth estate harus berperan sebagai pembentuk nilai kesetaraan di masyarakat. Tujuan penelitian ini untuk mengetahui konstruksi wacana kekerasan seksual terhadap perempuan dalam pemberitaan Republika Online (ROL). Peneliti menggunakan analisis wacana model Roger Fowler dkk, yang memandang bahasa sebagai praktik ideologi tertentu untuk membatasi pandangan khalayak terhadap sebuah realitas dengan menganalisis dimensi kosakata dan tata bahasa. Penelitian ini menggunakan pendekatan kualitatif untuk mengumpulkan data dengan melakukan observasi dan dokumentasi terhadap sepuluh berita tentang kekerasan seksual terhadap perempuan di ROL periode 23 November 2020 hingga 10 Maret 2021. Hasil penelitian menunjukkan bahwa ROL tidak berpihak kepada perempuan sebagai korban. Hal ini ditandai dengan marginalisasi posisi perempuan yang dominan dalam pemberitaan baik dari segi penamaan maupun penggambaran peristiwa kekerasan seksual. Marginalisasi tersebut tergambar dalam bentuk penggunaan kalimat pasif, nominalisasi, eufemisme, penamaan tidak mandiri dan sebagainya, yang justru akan melemahkan posisi perempuan dalam pemberitaan.
\end{abstract}

Kata kunci: analisis wacana; kekerasan seksual; perempuan; media online; Republika

Korespondensi: Nur Fajrah Safira, S.I.Kom., Fakultas Ilmu Sosial dan Ilmu Politik Universitas Tadulako, Jalan Soekarno-Hatta, Km 9, Kec. Mantikulore, Kota Palu, Sulawesi Tengah 94118, Email: nurfajrah25@gmail.com

Menyerahkan: November 2021, Diterima: Januari 2022, Terbit: Januari 2022

ISSN: 2549-0559 (cetak), ISSN: 2549-1946 (online), Website: http://jurnal.unpad.ac.id/kajian-jurnalisme 
178 | Kajian Jurnalisme

Volume 05 Nomor 02 Tahun 2022

DOI: $10.24198 / j \mathrm{kj} . v 5 \mathrm{i} 2.36524$

\section{PENDAHULUAN}

Kekerasan seksual merupakan sebuah isu yang sangat penting untuk dibahas segala hal tentangnya karena dapat terjadi secara berulang kepada siapa saja serta di mana saja. Komnas Perempuan mendefinisikan kekerasan seksual sebagai upaya merendahkan, menyerang, menghina dan/atau perbuatan lain, kepada tubuh yang dikaitkan dengan hasrat seksual, nafsu perkelaminan, serta fungsi reproduksi, melalui pemaksaan, berlawanan dengan kemauan seorang individu, ataupun perbuatan lainnya yang membuat seorang individu tidak kuasa menyatakan persetujuannya dengan leluasa, yang disebabkan oleh kepincangan relasi kuasa, relasi gender serta penyebab lain, dengan konsekuensi berupa kesengsaraan dan penderitaan terhadap seksual, fisik, psikis, kerugian secara politik, ekonomi, sosial, serta budaya (MaPPI FHUI, 2018).

Dewasa ini, masyarakat Indonesia masih berpegang pada budaya atau kebiasaankebiasaan yang sifatnya tergolong patriarki, di mana terjadi penguatan terhadap derajat lakilaki sedangkan derajat perempuan dilemahkan. Stigma yang melekat pada perempuan akibat penerapan budaya ini menimbulkan kesewenangan yang berujung pada upaya mendominasi (Setiawan \& Farida, 2020). Hal ini semakin diperkuat dengan dirilisnya Catatan Tahunan (CATAHU) 2020 oleh Komnas Perempuan yang menunjukkan peningkatan kasus kekerasan yang dialami perempuan sebanyak delapan kali lipat atau 792\% selama lebih dari satu dekade (Pratiwi, 2020). Angka kasus kekerasan tersebut, memberikan efek yang sangat serius tidak hanya bagi perempuan, namun juga lingkungan di sekelilingnya. Saat ini, isu kekerasan seksual tidak hanya menjadi persoalan individu tapi persoalan global yang menuntut banyak golongan ikut andil di dalamnya, termasuk media massa. Pers, sebagai salah satu penggerak di media massa tentu saja memainkan peran yang sangat penting dalam membahas isu tersebut. Pers bahkan digadang-gadang sebagai kekuatan keempat (the fourth estate) di dalam sistem kenegaraan sesudah legislatif, eksekutif, dan yudikatif (Valerisha, 2016).

Peranan media massa pada dimensi kehidupan masyarakat saat ini kian pesat. Hal tersebut nampak dengan munculnya media online yang bersifat multimedia, sehingga para jurnalis yang berkecimpung di dunia pers dapat melengkapi berita yang dipublikasikannya dengan audio-video. Menurut Tom Clarke berita atau NEWS merupakan akronim dari North, East, West, dan South, yang bermakna pemuas nafsu keingintahuan manusia dengan memberi kabar dari segala penjuru (Gangga, 2018). Demi memuaskan keinginan tersebut, masyarakat tidak lagi bergantung pada media-media konvensional. Budaya internet semakin merajalela sehingga masyarakat memilih media online sebagai media rujukan untuk mencari informasi (Romli, 2012).

Di dalam pemberitaan media online, perempuan kerap kali mendapatkan stigma serta stereotip yang dilekatkan oleh masyarakat kepada dirinya berdasarkan prasangka subjektif dan tidak tepat. Ketika perempuan menggunakan pakaian seksi, maka masyarakat akan melabelinya sebagai perempuan tidak baik. Sehingga, ketika wartawan menulis berita dengan judul "Joko Perkosa Anaknya yang Baru Kawin karena Terlalu Seksi dan Cantik," maka akan terbentuk asosiasi antara bentuk fisik perempuan dengan tindakan perkosaan, seakan perkosaan itu memperoleh dasar pembenaran. Masyarakat akan beranggapan bahwa perkosaan itu ada dasarnya, anaknya terlalu seksi dan cantik, jadi wajar jika laki-laki terangsang (Eriyanto, 2011). Penghakiman akan tertuju pada korban yang dianggap menjadi penyebab, karena penggunaan diksi oleh wartawan yang bias dalam beritanya. Perhatian masyarakat sebagai pembaca akan tertuju pada keseksian dan kecantikan perempuan dibandingkan kekejaman pelaku kekerasan.

Pilihan kosakata dan tata bahasa oleh wartawan merupakan praktik ideologi yang menyediakan alat bagaimana realitas seharusnya dipahami oleh khalayak. Republika sebagai 
media berideologi Islam yang lahir pada orde baru menjadi koran pertama di Indonesia yang tampil dalam dunia internet. Republika berkeinginan menampilkan Islam dalam wajah moderat dan menjadi saluran aspirasi umat serta menumbuhkan pluralisme di Negara Kesatuan Republik Indonesia (Republika, 2018). Sejalan dengan falsafah dasar Republika yang tetap mengedepankan komunitas muslim sebagai basis pengunjungnya, maka peneliti tertarik menggunakan media online Republika sebagai subjek penelitian untuk mengetahui bagaimana perspektif media berideologi Islam dalam memberitakan kasus kekerasan seksual terhadap perempuan.

Peneliti mengacu pada analisis wacana model Roger Fowler, Robert Hodge, Gunther Kress, dan Tony Trew sebagai bahan analisa. Roger Fowler dkk, melakukan pendekatan critical linguistics yang memandangi bahasa sebagai praktik dari aktivitas sosial yang digunakan sebuah kelompok-kelompok untuk meneguhkan dan menyebarluaskan ideologinya, di mana bahasa mengonstruksi bagaimana realitas dunia dipahami, sehingga memberikan kemungkinan seorang individu atau kelompok untuk memberikan kontrol serta mengatur pengalaman terhadap realitas sosial, sebab media menjadi agen pengonstruksian sosial yang merumuskan realitas, ideologilah yang pada akhirnya akan menentukan pandangan kelompok berdaya terhadap realitas yang ada (Eriyanto, 2011).

Di dalam penelitian tersebut, peristiwa dalam lingkup sejenis dapat digambarkan melalui cara berbeda tergantung dari pengalaman budaya, sosial, dan politik, di mana perkosaan dapat diistilahkan dengan memperkosa, meniduri, menggagahi, memperawani, dan sebagainya, dengan pemahaman bahwa bahasa bukanlah hal teknis, tetapi praktik terhadap sebuah ideologi tertentu, sebab perbedaan bahasa akan menghasilkan realitas yang berbeda pula saat diterima oleh masyarakat (Eriyanto, 2011).

Terdapat sejumlah penelitian yang selaras dengan judul yang digunakan oleh peneliti. Penelitian Rahmaniar et al. (2021) menunjukkan hasil bahwasanya ideologi serta kekuasaan dapat memberi batasan, klasifikasi dan pertarungan wacana. Selanjutnya, penelitian Zamzuardi dan Syahrul (2019) mengungkapkan bahwa di zaman globalisasi masih terdapat berita yang memarginalisasi dan merugikan kaum perempuan dalam bentuk pelemahan posisi perempuan, misalnya, ketika perempuan bepergian sendirian, memiliki postur tubuh yang bongsor, wajah yang cantik dan juga dalam kondisi yang sepi diperlakukan dengan hal yang tak pantas. Penelitian Chandradewi et al. (2014) menyimpulkan bahwasanya dalam pemberitaan kasus korupsi, Bali Post dan Jawa Post cenderung menulis berita ke dalam bentuk disfemisme sehingga berefek pada pemojokan subjek yakni koruptor di dalam pemberitaan. Penelitian terdahulu tersebut umumnya menggunakan konteks media yang berekosistem tanpa membawa unsur agama di dalam medianya. Jadi, belum tentu sama hasilnya pada media yang berkonteks agama, yakni Islam. Oleh karena itu, rumusan masalah yang akan peneliti bahas adalah bagaimana wacana kekerasan seksual terhadap perempuan dikonstruksi oleh Republika Online (ROL)?

\section{METODE}

Penelitian ini menerapkan metode kualitatif berdasarkan penelitian pada deskripsi berita kekerasan seksual terhadap perempuan di Republika Online (ROL). Subjek dari penelitian ini adalah Republika Online (ROL) dengan objek penelitiannya yakni sepuluh berita tentang kekerasan seksual terhadap perempuan. Adapun korpus dalam penelitian ini adalah berita kekerasan seksual terhadap perempuan selama periode 23 November 2020 sampai 10 Maret 2021. Periode tersebut dipilih karena terdapat rangkaian enam belas hari anti kekerasan terhadap perempuan dan international women's day di dalamnya. Berita tersebut dianalisis menggunakan analisis wacana model Roger Fowler dkk. Analisis ini mengacu pada dua 
180 | Kajian Jurnalisme

Volume 05 Nomor 02 Tahun 2022

DOI: $10.24198 / j \mathrm{kj} . v 5 \mathrm{i} 2.36524$

dimensi, yakni kosakata serta tata bahasa. Kedua dimensi tersebut dianalisis secara sistematis melalui observasi dan dokumentasi.

Tabel 1. Kerangka Analisis Model Roger Fowler

\begin{tabular}{|c|c|}
\hline Dimensi & Yang diamati \\
\hline Kosakata & $\begin{array}{l}\text { Pilihan kosakata yang digunakan untuk menggambarkan } \\
\text { peristiwa: kosakata apakah yang dipakai untuk menggambarkan } \\
\text { kekerasan seksual, apakah persetubuhan, perkosaan, digagahi, } \\
\text { disetubuhi, dsb (Eriyanto, 2011). } \\
\text { Pilihan kosakata yang digunakan untuk menggambarkan aktor } \\
\text { (agen) yang terlibat dalam peristiwa: pilihan kosakata apa yang } \\
\text { dipakai untuk menggambarkan perempuan sebagai korban, apakah } \\
\text { janda, perempuan cantik, wanita pekerja malam, dsb, demikian juga } \\
\text { dengan laki-laki sebagai pelaku, apakah memakai kata pemuda, orang } \\
\text { tak dikenal, segerombolan orang, dsb (Eriyanto, 2011). }\end{array}$ \\
\hline Tata Bahasa & $\begin{array}{l}\text { Bagaimana peristiwa digambarkan melalui rangkaian kata: misalnya } \\
\text { dalam berita kekerasan terhadap perempuan, bagaimana peristiwa itu } \\
\text { dijelaskan lewat kalimat, apakah perempuan sebagai korban dan laki- } \\
\text { laki sebagai pelaku, dan apakah laki-laki digambarkan sebagai pihak } \\
\text { berdosa atau tidak (Eriyanto, 2011). }\end{array}$ \\
\hline
\end{tabular}

Sumber: diolah dari Eriyanto (2011)

\section{HASIL DAN PEMBAHASAN}

\section{Tren Kekerasan Seksual di Palembang Meningkat}

Dimensi kosakata yang digunakan untuk menggambar peristiwa, meliputi: tren kekerasan seksual, pelecehan seksual dan perkosaan. Penggunan kata pelecehan seksual dan perkosaan pada berita tersebut mengandung arti yang sama dalam perspektif atau sudut pandang masyarakat, bahwa pelecehan seksual merupakan aktivitas seksual dengan cara sentuhan meliputi fisik dan non fisik yang menyasar seksualitas atau organ seksual korban dengan cara seperti, mempertunjukkan materi pornografi, sentuhan tubuh, main mata, ucapan bernuansa seksual, siulan, dan gerakan lainnya yang membuat korban merasa tidak nyaman dan direndahkan martabatnya, dan perkosaan sebagai bentuk serangan berupa pemaksaan dalam berhubungan intim dengan memasukkan jari tangan, penis, atau benda lainnya ke anal, mulut serta vagina korban (Komnas Perempuan, 2014).

Selanjutnya, yakni kosakata untuk menamai aktor yang terlibat, meliputi: remaja putri, pelajar tingkat SMP hingga mahasiswa dan pasangan prianya "kurang" sehat dalam berpacaran. Penamaan "pasangan prianya kurang sehat dalam berpacaran" membawa konsekuensi pemaknaan tertentu. Wartawan mengasosiasikan seakan laki-laki yang kurang sehat dalam menjalin hubungan adalah penyebab laki-laki tersebut memperkosa. Sebenarnya si pelaku memiliki sifat yang baik, hanya karena cara berpacarannya tidak sehat, maka ia melecehkan dan memperkosa. Penggunaan kata "kurang sehat" juga seolah ingin memberitahukan bahwa kasus kekerasan seksual dalam hubungan tidak cukup pantas untuk dikategorikan sebagai hubungan yang "tidak sehat". Kata "kurang" menunjukkan bahwa kekerasan seksual yang dialami oleh perempuan tidak seberapa, atau bahkan sepele. Olehnya, tindakan memperkosa tersebut tidak digambarkan sebagai perbuatan buruk dari pelaku, tetapi pengaruh kurang sehat dari cara berpacarannya.

Kemudian, pada dimensi tata bahasa menurut pemikiran Roger Fowler, bukanlah suatu hal yang bersifat statis, karena susunannya dapat diubah, dihilangkan, dipertukarkan, serta 
dikombinasikan dengan kalimat lainnya untuk dirangkap kembali. Perubahan tersebut tidak hanya mengubah pola pengaturan kalimat, tapi juga makna dari bahasa yang digunakan secara menyeluruh. Tata bahasa dalam berita ini mengandung pasivasi dalam bentuk kalimat pasif, di mana aktor yang berperan sebagai pelaku disembunyikan atau tidak ditampilkan dalam struktur kalimat sebagai akibat dari penulisan berita yang ditulis dalam struktur kalimat pasif(Eriyanto, 2011). Pasivasi tersebut tergambar dalam struktur kalimat berikut:

Tabel 2. Kalimat Pasif Berita 1

\begin{tabular}{|c|c|c|c|}
\hline Predikat & Subjek (Sasaran) & Pelengkap & Keterangan \\
\hline $\begin{array}{c}\text { Tren Kekerasan } \\
\text { seksual }\end{array}$ & Terhadap perempuan & $\begin{array}{c}\text { Remaja putri di } \\
\text { Palembang }\end{array}$ & $\begin{array}{c}\text { Dalam kurun waktu beberapa } \\
\text { tahun terakhir dinilai } \\
\text { mengalami peningkatan }\end{array}$ \\
\hline
\end{tabular}

Sumber: diolah oleh Peneliti (2021)

Tabel 3. Kalimat Pasif Berita 1

\begin{tabular}{|c|c|c|c|}
\hline $\begin{array}{c}\text { Keterangan } \\
\text { (Sasaran) }\end{array}$ & Subjek & Pelaku & Predikat \\
\hline $\begin{array}{c}\text { Tindak kekerasan } \\
\text { yang dialami }\end{array}$ & Para remaja putri & Pasangan prianya & $\begin{array}{c}\text { Kurang sehat dalam } \\
\text { berpacaran, pelecehan } \\
\text { seksual, dan perkosaan }\end{array}$ \\
\hline
\end{tabular}

Sumber: diolah oleh Peneliti (2021)

Susunan kalimat tidak hanya dikorelasikan dengan permasalahan metode penulisan dan teknis kebahasaan semata, karena bentuk kalimat menjadi penentu makna apa yang akan dihasilkan oleh kalimat yang telah disusun sedemikian rupa (Eriyanto, 2011). Di dalam kalimat pasif, yang ditonjolkan pertama kali bukanlah subjek pelaku, tetapi korban. Bentuk kalimat pasif bukan hanya tidak menonjolkan posisi pelaku, tapi juga dapat dihilangkan dalam struktur kalimat, sebab pelaku hanya berperan sebagai keterangan, sedang sasaran yang dikenai akan menjadi titik sentral. Sehingga nampak jelas, dengan menuliskan kalimat "pasangan prianya kurang sehat dalam pacaran," wartawan seolah ingin memberitahukan dasar pembenaran atas kasus kekerasan seksual yang terjadi. Pelaku tidak menonjol dalam kasus ini.

\section{Remaja di Tasikmalaya Hamili Anak di Bawah Umur}

Dimensi kosakata yang digunakan untuk menggambarkan peristiwa, meliputi: hamili, pencabulan dan persetubuhan. Kosakata "hamili" dan "persetubuhan" merupakan bentuk eufemisme atau penghalusan makna dari pencabulan yang dilakukan oleh wartawan (Taufik \& Syamsudduha, 2021). Pemilihan kata eufemisme dalam konteks tersebut, menjadikan realitas kasar berubah menjadi realitas halus. Akibatnya, nalar khalayak tidak bisa melihat kenyataan yang sesungguhnya. Padahal dalam critical linguistics penamaan yang jelas merupakan titik penting dalam analisis.

Kosakata "pencabulan" secara definisi digolongkan ke dalam perkosaan kepada anak di bawah delapan belas tahun. R. Sughandi mengasumsikan pencabulan sebagai tindakan pemaksaan kepada seorang perempuan yang dilakukan oleh laki-laki tanpa ikatan pernikahan agar melakukan hubungan intim dengannya melalui ancaman kekerasan, di mana diwajibkan terjadi penetrasi antara kemaluan laki-laki ke kemaluan seorang perempuan hingga air maninya keluar (Ngawiardi, 2016).

Apabila ditelisik berdasarkan opini di atas, di mana pencabulan tersebut merupakan 
182 | Kajian Jurnalisme

Volume 05 Nomor 02 Tahun 2022

DOI: $10.24198 /$ jkj.v5i2.36524

tindakan seorang laki-laki yang melakukan pemaksaan, ancaman dan kekerasan terkait seksualitas terhadap perempuan yang tidak memiliki ikatan pernikahan dengannya, dan melalui hubungan seksual tersebut keluar air mani, maka unsur-unsur dari pencabulan tersebut bukan hanya kekerasan dan hubungan seksual, tapi juga unsur lain, yakni keluarnya air mani. Artinya, perbuatan tersebut tidak tergolong ke dalam pencabulan, apabila laki-laki dalam hal ini pelaku tidak mengeluarkan mani.

Opini yang tidak sependapat dalam mendefinisikan pencabulan tentang diharuskannya keluar air mani atau tidak disampaikan oleh pakar bernama Djisman Samosir dan Lamintang yang berasumsi bahwa pencabulan merupakan tindakan berupa ancaman serta kekerasan yang memaksa perempuan berhubungan seksual tanpa adanya ikatan pernikahan (Ngawiardi, 2016). Asumsi tersebut selaras dengan Komnas Perempuan yang mengategorikan pencabulan sebagai istilah lain dari perkosaan berupa pemaksaan dalam berhubungan badan dengan memasukkan alat kelamin, jari, atau benda lainnya ke anal, mulut, atau vagina korban. Serangan oleh pelaku dilakukan dengan penahanan, tekanan psikologis, kekerasan, ancaman kekerasan, dan penyelewengan kekuasaan (Komnas Perempuan, 2014).

Selanjutnya yakni kosakata yang digunakan untuk menggambarkan aktor yang terlibat, meliputi: remaja di Tasikmalaya, anak di bawah umur, 2 orang remaja berinisial TG (22) dan AJ (26) dan dua tersangka itu merupakan kakak beradik, serta NMS (13) dan DJN (14). Penggunaan kosakata "remaja" untuk menamai pelaku, secara definisi seharusnya tidak digunakan oleh wartawan. Karena, jika merujuk pada usia pelaku seperti yang diterangkan dalam berita yaitu berusia 26 dan 22 tahun, maka usia tersebut dikategorikan sebagai usia dewasa, hal ini berdasarkan pada Surat Edaran Nomor 7 Tahun 2012 yang dikeluarkan oleh Mahkamah Agung sebagai pedoman pelaksanaan tugas bagi pengadilan, yang menjelaskan usia delapan belas tahun atau sudah menikah sebagai kategori seseorang disebut dewasa (Dharma, 2015). Berdasarkan keterangan tersebut, maka pelaku merupakan seseorang yang telah menginjak usia dewasa, bukan remaja.

Berita berjudul "Remaja di Tasikmalaya Hamili Anak di Bawah Umur" memberikan penaman "anak di bawah umur" dan "NMS (13) dan DJN (14)" untuk menamai aktor yang menjadi korban dalam kasus pencabulan ini. Penamaan anak di bawah umur pada berita tersebut diberikan sesuai kategorisasi usia korban yang belum menginjak delapan belas tahun sesuai ketetapan UU No. 23 tahun 2002 tentang Perlindungan Anak, di mana anak di bawah umur dikategorikan sebagai seseorang yang masih berusia delapan belas tahun, termasuk anak yang masih berada di dalam kandungan (Satriya, 2011). Adapun penulisan nama korban dengan menggunakan inisial dilakukan oleh wartawan berdasarkan ketentuan dewan pers pada pasal lima, di mana wartawan tidak diperkenankan untuk menyiarkan dan menyertakan identitas korban serta anak yang menjadi pelaku kejahatan (Dewan Pers, 2017).

Bagi Roger Fowler dkk, tata bahasa merupakan satu kesatuan antara kategori dan proses, yang menampilkan penggambaran antara peristiwa dan objek yang bersangkutan. Oleh karena itu, dalam menggambarkan hubungan tersebut, maka Roger Fowler dkk, menganalisa kejadian menggunakan beberapa model, salah satunya yaitu model transitif yang menjadi bagian dari analisis sintagmatik. Model transitif berkorelasi terhadap proses, di mana satu sisi dianggap sebagai penyebab dari sebuah tindakan, dan sisi lainnya sebagai akibat dari tindakan tersebut (Eriyanto, 2011). Seperti yang terlihat pada kalimat pertama dan kedua berikut:

"Tersangka AJ diduga melakukan pencabulan kepada NMS (13), sementara TG melakukan pencabulan kepada DJN (14). Salah satu korban bahkan diketahui hamil akibat pencabulan ini." (Republika, 2020)

"Menurut Doni, pencabulan dilakukan beberapa kali kepada korban. Para tersangka melakukan pencabulan dengan memberikan minuman beralkohol kepada korban. Ketika 
korban tidak sadarkan diri, para tersangka baru melakukan aksinya." (Republika, 2020)

Kalimat pertama yang tergolong ke dalam model transitif menunjukkan tersangka berinisial AJ dan TG sebagai subjek yang melakukan pencabulan, sementara NMS yang berusia 13 tahun dan DJN yang berusia 14 tahun sebagai objek yang dicabuli oleh tersangka bahkan salah satunya hamil akibat pencabulan tersebut. Adapun pada kalimat kedua, berdasarkan hasil interogasi, para tersangka berperan sebagai subjek yang mencabuli korban dengan cara memberikan minuman beralkohol, sementara korban sebagai objek yang dicabuli saat dirinya sudah tidak sadarkan diri. Pencabulan terhadap anak yang dilakukan oleh pelaku dapat ditempuh dengan berbagai cara, berupa ancaman, bujuk rayu, paksaan, tekanan, bahkan tipuan, seperti yang dilakukan oleh AJ dan TG, dengan memberikan minuman beralkohol kepada korban. Kehamilan yang terjadi pada salah satu korban terjadi karena adanya pemaksaan penetrasi penis pelaku ke vagina korban, yang memungkinkan adanya resiko kehamilan. Kalimat ketiga yang tergolong dalam analisis sintagmatik termasuk ke dalam model relasional ekuatif, yakni hubungan antara sesama kata benda (Eriyanto, 2011). Penggalan kalimat tersebut menunjukkan bahwa kedua tersangka merupakan anggota dari komunitas anak punk di Kabupaten Tasikmalaya dan memiliki hubungan saudara. Hal tersebut nampak jelas pada kalimat berikut:

"Doni mengatakan, kedua tersangka memang tergabung dalam komunitas anak punk yang bermarkas di Kecamatan Rajapolah, Kabupaten Tasikmalaya. Kedua tersangka yang merupakan kakak beradik itu melakukan aksinya di markas komunitas mereka." (Republika, 2020)

Tata bahasa dalam berita ini juga mengandung pasivasi, di mana terdapat satu kalimat yang ditulis dalam bentuk kalimat aktif, dan satu kalimat lain dalam bentuk pasif. Penulisan kalimat dalam bentuk aktif menjadikan subjek (pelaku) dari kasus pencabulan tersebut sebagai titik sentral, sedangkan dalam bentuk kalimat pasif fokus yang ingin dikomunikasikan kepada pembaca lebih mengarah kepada diri objek, bukannya subjek, yang hendak disampaikan adalah kemalangan korban yang hamil ketika usianya masih tergolong di bawah umur. Struktur kalimat pasif, membuat posisi pelaku di dalam kalimat aktif hanya bernilai keterangan, bahkan dapat dihilangkan posisinya di dalam struktur kalimat. Bentuk Perbandingan struktur kalimat aktif dan pasif tersebut dapat digambarkan sebagai berikut:

Tabel 4. Perbandingan Kalimat Aktif dan Pasif Berita 2

\begin{tabular}{|l|l|}
\hline \multicolumn{1}{|c|}{ Aktif } & \multicolumn{1}{|c|}{ Pasif } \\
\hline $\begin{array}{l}\text { Remaja di Tasikmalaya hamili anak di bawah } \\
\text { umur }\end{array}$ & $\begin{array}{l}\text { Korban berinisial DJN hamil dua bulan akibat } \\
\text { persetubuhan ini }\end{array}$ \\
\hline
\end{tabular}

Sumber: diolah oleh Peneliti (2021)

Di dalam kalimat aktif, ketika subjek atau pelaku dihilangkan, kalimat tersebut tidak akan berbunyi sama sekali, sebab posisi subjek atau pelaku sangat sentral karena berperan untuk memberikan penjelasan mengenai siapa pelaku dari suatu tindakan. Akan tetapi, dalam kalimat pasif, kalimat tetap akan terbaca bahkan saat pelaku ditiadakan dari struktur kalimat. Artinya, hadir atau tidaknya pelaku, tidak memiliki pengaruh terhadap pembacaan kalimat, sebab yang menjadi titik sentral adalah sasaran atau korban. Posisi pelaku dalam kalimat pasif hanyalah bersifat keterangan, sehingga apabila dihilangkan, tidak akan memberikan pengaruh secara gramatikal. Sebagai keterangan, di dalam kalimat pasif tidak harus diisi oleh pelaku tetapi bisa dengan keterangan lain, bahkan dihilangkan, seperti yang terlihat dalam tabel di atas. Menurut Roger Fowler dkk, upaya mengubah struktur kalimat ke dalam bentuk pasif, merupakan tindakan manipulasi sintaksis, sebab perubahan kalimat menjadi pasif membuat 
184 | Kajian Jurnalisme

Volume 05 Nomor 02 Tahun 2022

DOI: $10.24198 / \mathrm{jkj} . \mathrm{v} 5 \mathrm{i} 2.36524$

pelaku tidak hanya disembunyikan sosoknya dalam pemberitaan, tapi juga dapat dihilangkan (Eriyanto, 2011).

\section{Polres Periksa Kekerasan Seksual Tiga Anak di Bawah Umur}

Dimensi kosakata yang digunakan untuk menggambarkan peristiwa, meliputi: kekerasan seksual, ditindih dan diraba, serta melihat film dewasa. Kosakata ditindih dan diraba, serta melihat film dewasa merupakan bentuk perbuatan kekerasan seksual yang tergolong dalam kategori pelecehan seksual. Berdasarkan penggunaan kosakata tersebut, sebagai pembaca, kita bisa melihat bahwasanya media massa dalam membuat pemberitaan tentang isu kekerasan seksual seolah memberikan kesan lebih tertarik menonjolkan sesuatu yang bersifat sensasional dibanding motif yang sebenarnya dari pelaku, apalagi yang menjadi korban kasus ini adalah anak-anak yang masih di bawah umur.

Selanjutnya yakni kosakata yang digunakan untuk menggambarkan aktor yang terlibat, meliputi: tiga anak perempuan yang masih di bawah umur, tetangga korban yang juga mantan guru ngaji, Udin dan tiga bocah perempuan. Penamaan terhadap korban tersebut mengindikasikan bahwasanya yang menjadi korban di dalam berita ini adalah anak di bawah umur. Jika didefinisikan berdasarkan UU Nomor 23 Tahun 2002 Tentang Perlindungan Anak Pasal 1 Ayat 1 disebutkan bahwa anak adalah seseorang yang belum berusia delapan belas tahun, termasuk anak yang masih dalam kandungan (Hutahaean, 2013).

Kalimat di dalam berita ini ditulis oleh wartawan dalam bentuk pasif, di mana secara gramatikal unsur pelaku dapat dihilangkan karena hanya bersifat keterangan. Maka, ada atau tidaknya pelaku tidaklah memengaruhi gramatikal kalimat, sebab unsur minimal sesuatu dikategorikan kalimat yakni subjek dan predikat. Oleh karena itu, pada kalimat aktif, kehadiran pelaku memiliki peranan penting, karena menempati posisi subjek. Kehadiran subjek di dalam kalimat tidak hanya krusial tapi juga syarat utama secara gramatikal sesuatu dikategorikan sebagai kalimat (Eriyanto, 2011). Berikut adalah struktur kalimat pasif tersebut:

Tabel 5. Kalimat Pasif Berita 3

\begin{tabular}{|c|c|c|c|}
\hline Subjek & Predikat & Objek & Keterangan \\
\hline Polres periksa & Kekerasan seksual & Tiga anak di bawah umur & $\ldots$ \\
\hline
\end{tabular}

Sumber: diolah oleh Peneliti (2021)

\section{Suami Guru PAUD Pelaku Kejahatan Seksual 3 Bocah Ditangkap}

Dimensi kosakata yang digunakan untuk menggambarkan peristiwa, meliputi: kejahatan seksual, terangsang dan bergairah. Kosakata tersebut mengindikasikan adanya perasaan bergairah, keinginan, hasrat atau kecenderungan seksual terhadap anak-anak, sehingga pelaku merasa terangsang dan menjadikan anak-anak sebagai preferensi seksualnya.

Selanjutnya yakni kosakata yang digunakan untuk menggambarkan aktor yang terlibat, meliputi: suami guru PAUD, suami guru PAUD berinisial S (55), predator seks, tiga bocah dan tiga anak perempuan dengan inisial NA (5), NJ (10), dan SP (5). Kosakata yang digunakan untuk menamai pelaku merupakan bentuk marginalisasi terhadap posisi perempuan, di mana wartawan tidak memberikan penamaan yang mandiri kepada pelaku, sehingga terjadi asosiasi antara pekerjaan istri sebagai tenaga pendidik dan perbuatan suami yang tidak terdidik. Posisi perempuan dalam hal ini istri si pelaku begitu dekat dengan idiom-idiom berupa kegagalan dalam mengurus hal domestik serta melaksanakan perannya di ruang publik. Kosakata selanjutnya adalah predator seks. Istilah tersebut merupakan sebuah metafora, yaitu pemakaian kata yang digunakan tidak berdasarkan makna sesungguhnya, melainkan sebuah kiasan 
berdasarkan perbandingan atau persamaan. Analoginya, predator diartikan sebagai seseorang atau hewan yang melakukan perburuan terhadap mangsa dan predator seks dianggap sebagai perburuan untuk mencari pasangan seksual. Adapun kalimat di dalam berita ini ditulis dalam bentuk aktif, di mana pelaku ditempatkan posisinya pada subjek. Sehingga akan tergambarkan bahwa pelaku telah melakukan sesuatu kepada korban, dengan penggambaran struktur kalimat sebagaimana berikut:

Tabel 6. Kalimat Aktif Berita 4

\begin{tabular}{|c|c|c|c|}
\hline Subjek (Pelaku) & Predikat & Objek (Sasaran) & Pelengkap \\
\hline Suami guru PAUD & $\begin{array}{c}\text { Pelaku kejahatan sek- } \\
\text { sual }\end{array}$ & Tiga bocah & Ditangkap \\
\hline
\end{tabular}

Sumber: diolah oleh Peneliti (2021)

\section{Cabuli Balita Empat Tahun, Polisi: Pelaku Bisa Dijerat PP Kimia}

Kosakata pertama yakni kosakata yang digunakan untuk menggambarkan peristiwa, yaitu: cabul, mencabuli. Kosakata cabul dan beberapa kosakata turunannya, yaitu cabuli, mencabuli, dicabuli dan pencabulan, merupakan bagian dari kekerasan seksual yang secara definisi digolongkan ke dalam perkosaan terhadap anak di bawah delapan belas tahun. Berikutnya yakni kosakata untuk menamai aktor yang terlibat dalam peristiwa, meliputi: balita 4 tahun, Akhmad Suprianto 38, Warga di Desa Warunung, Kecamatan Pacet, anak di bawah umur dan pedofil (Republika, 2021a). Kata pedofil yang disematkan pada pelaku merupakan gangguan seksual berupa dorongan atau gairah seksual terhadap anak di bawah umur. Pedofilia sebagai kelainan atau gangguan kejiwaan, dapat memicu seseorang melakukan tindakan dengan cara menjadikan anak sebagai sasaran dan instrumen dari perilaku pelampiasan nafsu seksual (Prasetyo, 2018).

Kalimat dalam berita ini mengandung replika kekerasan dan tergolong ke dalam pornografi, yang semestinya tidak ditulis oleh wartawan karena bertentangan dengan kode etik jurnalistik pada pasal empat. Berita tersebut tergolong ke dalam pornografi karena menggambarkan perilaku seksual secara jelas dan terperinci dengan tujuan memberikan rangsangan atau hasrat seksual kepada para pembaca, serta termuat di dalam media (Fathurizki \& Malau, 2018). Hal tersebut tertera pada penggalan kalimat "dalam aksinya, lanjut alumnus Akpol 2020 ini, pelaku memasukkan jari ke alat kemaluan korban yang masih berumur empat tahun. Kemudian mengeluarkan alat kelamin tersangka dan melakukan masturbasi ataupun onani sampai keluar sperma dari tersangka" (Republika, 2021a).

\section{Bejat... Cabuli Anak Tiri Sejak 2018, Pria Ini Ditangkap}

Kosakata pertama yakni kosakata yang digunakan untuk menggambarkan peristiwa, meliputi: cabuli, iseng memegang payudara dan perbuatan bejat. Penggunaan kata "iseng" dalam kosakata tersebut seakan membuat kasus kekerasan seksual menjadi sesuatu hal yang sepele. Sehingga pembaca akan dibatasi pandangannya terhadap sebuah realitas, bahwasanya pelaku tidak berniat untuk melakukan kekerasan seksual kepada korban. Pembaca diarahkan pada sebuah realitas bahwa seorang ayah yang memegang payudara anaknya hanyalah sebuah keisengan belaka. Pemakaian kata-kata yang berbeda antara "iseng memegang payudara" dengan "memegang payudara" haruslah dipahami tidak hanya sekadar persoalan istilah saja, sebab kosakata tersebut dapat memunculkan makna dan definisi tertentu saat dikonsumsi khalayak.

Selanjutnya yaitu kosakata untuk menamai aktor yang terlibat di dalam peristiwa, meliputi: 
186 | Kajian Jurnalisme

Volume 05 Nomor 02 Tahun 2022

DOI: $10.24198 / \mathrm{jkj} . v 5 \mathrm{i} 2.36524$

anak tiri, pria berinisial RDP (40) tahun, perempuan berinisial ASK, berusia 11 tahun dan ayah tiri. Di dalam KBBI, pria didefinisikan sebagai laki-laki dewasa. Apabila membahas persoalan pria yang didefinisikan sebagai laki-laki dewasa, maka kedewasaan tersebut secara harfiah mengacu pada persoalan kematangan usia, serta pikiran dan sudut pandang. Definisi tentang pria tentu membawa konsekuensi makna tertentu bagi pembaca, terlebih dalam analisis Roger Fowler, terdapat penekanan bahwa kosakata tidak hanya berfungsi sebagai pemberi identitas atau penanda, tapi juga memiliki hubungan dengan suatu ideologi. Kosakata "pria" untuk menamai pelaku pun tak ayal menjadikan bahasa sebagai senjata terselubung. Sebab, menurut Karlina Leksono bahasa dipandang mempunyai kemampuan untuk memberikan pernyataan melebihi apa yang disampaikan. Bahasa memuat semua tanda, istilah, konsep, maupun labellabel yang pantas untuk laki-laki dan perempuan.

Kalimat dalam berita ini tergolong ke dalam model transitif yang menggambarkan interpretasi sebab akibat, di mana pelaku serta penerima tindakan dilakukan oleh masingmasing satu entitas yang terlibat. Berita ini menunjukkan kenyataan bahwa tubuh perempuan pada umumnya seperti payudara, bibir, bokong, paha dan sebagainya sering dimuat dalam media sebagai modal simbolik ketimbang sekadar modal biologis. Bagian dari tubuh perempuan dianggap sebagai bentuk erotisme dan dijadikan fetish atau sesuatu yang dipujapuji hingga terkadang dilecehkan sebab dianggap mempunyai getaran yang memunculkan hasrat, rangsangan, serta gairah tertentu (Fernandez, 2013).

\section{Istri Komedian Isa Bajaj jadi Korban Pelecehan Seksual}

Kosakata pertama yakni kosakata yang digunakan untuk menggambarkan peristiwa, meliputi: pelecehan seksual dan memperlihatkan kemaluan. Tindakan yang dilakukan oleh pelaku dengan memperlihatkan kemaluan kepada korban merupakan bentuk dari pelecehan seksual, sehingga jelaslah klasifikasi kekerasan seksual yang digunakan oleh wartawan. Tata bahasa pada hakikatnya mengklasifikasikan sebuah realitas untuk dikategorisasikan sehingga menjadi pembeda dengan realitas lainnya. Klasifikasi berfungsi sebagai pengontrol pengalaman dan informasi (Eriyanto, 2011). Selanjutnya yakni kosakata yang digunakan untuk menggambarkan aktor yang terlibat, meliputi: istri komedian Isa Bajaj, istri komedian Isa Bajaj berinisial RM dan seorang pria (Republika, 2021b). Caldas-Coulthard pernah membuat sebuah penelitian tentang bagaimana laki-laki dan perempuan digambarkan lewat penamaan mereka. Berdasarkan penelitian tersebut, perempuan banyak disebutkan dengan penamaan yang tidak mandiri, seperti nyonya, yang diikuti dengan nama suami (Eriyanto, 2011).

Penamaan untuk menggambarkan perempuan sebagai korban dalam berita tersebut menjadi pembenaran atas hasil penelitian yang dilakukan oleh Caldas-Coulthard. Penamaan tidak mandiri tersebut terlihat dari pengasosiasian antara korban dan suaminya yang merupakan seorang pesohor, sehingga beritanya dikemas untuk kepentingan komersial. Sehingga, berita tersebut memiliki nilai pikat tersendiri agar menarik minat pembaca untuk mengonsumsi beritanya. Padahal, di sisi lain, hal tersebut akan membuat posisi perempuan tersudut, bahkan dalam bahasa sekali pun.

Kalimat dalam berita ini ditulis oleh wartawan dalam bentuk pasif. Bentuk kalimat pasif bukan hanya tidak menonjolkan posisi pelaku, bahkan sosoknya dapat dihilangkan dari struktur kalimat. Hal ini berkaitan dengan sifat dari struktur kalimat itu sendiri. Kalimat aktif selalu membutuhkan kehadiran subjek pelaku, sebab tanpa kehadirannya, kalimat tersebut tidak akan ada artinya. Di dalam pemberitaan mengenai pelecehan seksual tersebut, jika dibahasakan dalam bentuk kalimat aktif, maka posisi pelaku harus disertakan di dalam kalimat. Sebaliknya, di dalam kalimat pasif posisi pelaku tidak diperlukan kehadirannya, bisa dihadirkan, bisa 
pula dihilangkan. Hal ini karena dalam kalimat berbentuk pasif, posisi pelaku hanya bersifat keterangan, yang berperan sebagai titik sentral dalam kalimat tersebut adalah korban. Olehnya, membuat kalimat dalam bentuk pasif akan memberikan efek pada penghilangan pelaku (Eriyanto, 2011).

\section{Jadi Mucikari Prostitusi Online Anak di Bawah Umur, Mahasiswa Diciduk}

Kosakata pertama yakni kosakata yang digunakan untuk menggambarkan peristiwa, yaitu prostitusi online. Dewasa ini, prostitusi di Indonesia telah berkembang sebagai ladang bisnis yang sangat menjanjikan, dimodifikasi sangat apik, melibatkan jaringan serta sindikasi dengan taraf besar melalui pemanfaatan media online untuk wadah pemasaran. The Industrial Vagina, The Political Economy of the Global Sex Trade, sebuah buku yang ditulis oleh Sheila Jeffreys menyebut jika di saat ini jasa layanan prostitusi memanglah sudah tumbuh ke dalam sebuah industri tertentu yang sangat menguntungkan. Di dalam bisnis pelacuran, yang berlaku yakni hukum permintaan serta penawaran. Selama permintaan pasar ada, sesering apapun aparat kepolisian melaksanakan patroli, bisnis layanan pelacuran ini dapat dipastikan akan tetap merajalela serta menciptakan keuntungan. Prostitusi online menjadikan perangkat tubuh seorang perempuan tidak lagi semata-mata mempunyai nilai guna yang privat, melainkan komoditas yang mempunyai nilai jual sehingga dapat dinikmati siapa saja yang sanggup membayar berdasarkan angka penawaran (Malik, 2019).

Selanjutnya yakni kosakata untuk menggambarkan aktor yang terlibat, meliputi: anak di bawah umur, mahasiswa, seorang mahasiswa yang menjadi mucikari, dan mahasiswa itu adalah AP (21). Mucikari merupakan sebutan untuk induk semang atau germo yang diistilahkan sebagai pihak yang melakukan penampungan terhadap PSK serta laki-laki hidung belang di dalam melaksanakan transaksi seks, di mana germo akan mendapat imbalan sekian persen dari transaksi tersebut (Yanto, 2015). Prostitusi online melibatkan peran mucikari yang mengarah pada hubungan antara anak buah dan pimpinan di sebuah lokalisasi atau media sosial yang digunakan untuk menjajakan para PSK. Mucikari yang dimaksud adalah orang perempuan maupun laki-laki dengan mata pencaharian penuh atau sambilan dalam membiayai, mengadakan, menipu, membuka, menyewakan, serta mengurus tempat sebagai tujuan praktik seks komersil (Jaya \& Basri, 2014).

Tata bahasa di dalam berita ini menunjukkan realita bahwasanya seorang mucikari bukan hanya dilakoni oleh orang dewasa, akan tetapi, mahasiswa dan anak di bawah umur sekali pun dapat melakoni profesi tersebut. Anak-anak dapat dijumpai di lokasi pelacuran, atau situs dan aplikasi yang biasa digunakan untuk memperkenalkan para PSK dengan pelanggan (Ngawiardi, 2016). Prostitusi saat ini mulai menjelma ke berbagai bentuk, jika dahulu pelayanan seks dilakukan di daerah-daerah lokalisasi, kini dengan adanya bantuan teknologi, pekerja seks dapat memberikan pelayanan baik dirumah, kontrakan, hotel, bahkan kamar kos, berdasarkan perjanjian antara pihak yang bersepakat, hal tersebut terlihat dari lokasi penggerebekan yang dilakukan oleh Tim Siber tepatnya di sebuah hotel yang terletak di perbatasan Surabaya dan Sidoarjo.

\section{Polisi Tangkap Remaja Cabuli Anak 15 Tahun di Deli Serdang}

Kosakata "pencabulan" secara definisi digolongkan ke dalam perkosaan kepada anak di bawah delapan belas tahun. R. Sughandi mengasumsikan pencabulan sebagai tindakan pemaksaan kepada seorang perempuan yang dilakukan oleh laki-laki tanpa ikatan pernikahan agar melakukan hubungan intim dengannya melalui ancaman kekerasan, di mana diwajibkan terjadi penetrasi antara kemaluan laki-laki ke kemaluan seorang perempuan hingga air maninya 
188 | Kajian Jurnalisme

Volume 05 Nomor 02 Tahun 2022

DOI: $10.24198 /$ jkj.v5i2.36524

keluar (Ngawiardi, 2016).

Apabila ditelisik berdasarkan opini di atas, di mana pencabulan tersebut merupakan tindakan seorang laki-laki yang melakukan pemaksaan, ancaman dan kekerasan terkait seksualitas terhadap perempuan yang tidak memiliki ikatan pernikahan dengannya, dan melalaui hubungan seksual tersebut keluar air mani, maka unsur-unsur dari pencabulan tersebut bukan hanya kekerasan dan hubungan seksual, tapi juga unsur lain, yakni keluarnya air mani. Artinya, perbuatan tersebut tidak tergolong ke dalam pencabulan, apabila laki-laki dalam hal ini pelaku tidak mengeluarkan mani. Opini yang tidak sependapat dalam mendefinisikan pencabulan tentang diharuskannya keluar air mani atau tidak disampaikan oleh pakar bernama Djisman Samosir dan Lamintang yang berasumsi bahwa pencabulan merupakan tindakan berupa ancaman serta kekerasan yang memaksa perempuan berhubungan seksual tanpa adanya ikatan pernikahan (Ngawiardi, 2016).

Selanjutnya yakni kosakata yang digunakan untuk menggambarkan aktor yang terlibat, yakni: remaja, anak 15 tahun, perempuan berusia 15 tahun, ketiga remaja itu adalah FYG alias Gea (18), MAZ (18), MTS alias Runa (18) dan inisial D (Republika, 2021c). Penulisan nama pelaku dengan inisial atau alias (nama samaran) dilakukan oleh wartawan berdasarkan ketentuan dewan pers pada pasal lima, di mana wartawan tidak diperkenankan untuk memberikan keterangan mengenai identitas korban asusila serta pelaku yang masih tergolong usia anak (Dewan Pers, 2017).

Tata bahasa dalam berita ini menunjukkan bahwasanya perempuan masih dijadikan sebagai objek seksual. Yasraf Amir Piliang melalui tulisannya berjudul "Masih Adakah Aura Wanita di Balik Euphoria Media mengemukakan bahwa fungsi tubuh telah bergeser dari fungsi organis/biologis/reproduktif ke arah fungsi ekonomi politik, khususnya fungsi tanda. Tubuh perempuan dimuati dengan modal simbolik ketimbang biologis, sehingga tubuhnya dipuja dan dilecehkan dalam waktu yang sama. Di dalam wacana media, perempuan diposisikan bukan sebagai subjek pengguna bahasa, tetapi sebagai objek tanda. Bibir, mata, pipi, rambut, paha, betis, pinggul, perut, buah dada, semuanya menjadi fragmen tanda di dalam masyarakat patriarki, yang digunakan untuk menyampaikan makna tertentu. Semua fragmen tanda itu menjadi objek fetish, yang membuat tubuh perempuan mengandung unsur hasrat dan seksual di dalamnya. Hal ini menjadikan tubuh atau fragmen tubuh perempuan sebagai penanda yang dikaitkan dengan makna tertentu, misalnya, bentuk tubuh yang indah ekuivalen dengan gitar Spanyol, bibir tebal ekuivalen dengan sensualitas permen yang manis dan sebagainya, sehingga tubuh perempuan dieksploitasi dengan sesuatu yang bersifat erotis.

\section{Anak di Bawah Umur jadi Korban Eksploitasi dan Prostitusi}

Kosakata pertama yakni kosakata yang digunakan untuk menggambarkan peristiwa, meliputi: eksploitasi, prostitusi, hubungan badan, persetubuhan, meniduri dan pencabulan. Kosakata hubungan badan, persetubuhan dan meniduri merupakan bentuk eufemisme atau penghalusan makna dari eksploitasi dan pencabulan yang dilakukan oleh pelaku. Jadi, hubungan seksual di dalam berita tersebut digambarkan sebagai bentuk rasa suka sama suka antara kedua belah pihak yang sedang menjalin asmara, padahal hubungan badan tersebut bagi pelaku merupakan sebuah modus mengeksploitasi korban, sehingga ia bisa terjerumus ke dunia prostitusi. Sedangkan kata persetubuhan dan meniduri digambarkan sebagai bentuk lain dari pencabulan. Pemilihan kata eufemisme dalam konteks tersebut, menjadikan realitas kasar berubah menjadi realitas halus. Akibatnya, nalar khalayak tidak bisa melihat kenyataan yang sesungguhnya. Padahal dalam critical linguistics penamaan yang jelas merupakan salah satu titik penting dalam analisis. 
Selanjutnya yakni kosakata yang digunakan untuk menggambarkan aktor yang terlibat, meliputi: 91 anak di bawah umur, 195 orang dewasa, germo, joki (mucikari), 15 tersangka ini berinisial WH, AWL, YY, AG, AR, KN, SI, SA, SH, CGA, YF, PK, AS dan seorang perempuan berinisial AI, serta MNA merupakan WNA. Anak-anak kerap kali mengalami kejahatan yang berkaitan dengan norma kesusilaan (Yunastian, Pujiyono, \& Purwoto, 2017). Semisal, Anak di bawah umur yang terjerumus ke dalam lubang prostitusi yang memiliki kecenderungan orientasi dalam jangka pendek dan mudah dibujuk rayu, sehingga kapasitas pengambilan keputusan dalam hidupnya belum dianggap rasional (Pranawati, Ginanjar, Matindas, \& Irwanto, 2020). Identitas tersangka ditulis dalam bentuk inisial, karena wartawan berpedoman pada hak tolak, salah satunya yang dinyatakan dalam pasal tujuh) kode etik jurnalistik, yang menyatakan bahwa: Wartawan Indonesia memiliki hak tolak untuk melindungi narasumber yang tidak bersedia diketahui identitas maupun keberadaannya, menghargai ketentuan embargo, informasi latar belakang dan off the record sesuai dengan kesepakatan. Adapun penjelasan dari pasal tersebut, menyebutkan bahwa: embargo adalah penundaan pemuatan atau penyiaran berita sesuai dengan permintaan narasumber. Informasi latar belakang adalah segala informasi atau data dari narasumber yang disiarkan atau diberitakan tanpa menyebutkan narasumbernya. Off the record adalah segala informasi atau data diri narasumber yang tidak boleh disiarkan atau diberitakan" (Dewan Pers, 2017).

Kalimat dalam berita ini mengandung nominalisasi. Suatu kalimat digolongkan ke dalam nominalisasi apabila bagian dari kalimat, partisipan, maupun tindakan digambarkan ke dalam bentuk kata benda, yakni perubahan dari kata kerja menjadi kata benda. Hal tersebut ditandai dengan pengimbuhan "pe-an," akibatnya kata mencabuli menjadi pencabulan. Hal semacam ini membuat pembaca lebih menyoroti tindakan pelaku dibandingkan sosok pelaku itu sendiri. Dengan menggunakan kosakata persetubuhan dan pencabulan, maka peran aktor sebagai pelaku diturunkan dalam suatu peristiwa (Eriyanto, 2011).

Di dalam bisnis prostitusi online, penggunaan aplikasi baik di Michat, Wechat dan WhatsApp, para mucikari biasanya menyamarkan identitasnya dengan kata-kata "melayani pijat," "layanan manja," "tempat cerita," atau "tempat hangat." Namun, kalimat atau katakata di atas sebenarnya mengindikasikan bahwa mereka menyediakan layanan seks (Irawan, Gultom, \& Amsani, 2019). Adapun kalimat yang menyatakan bahwa korban ditawarkan pada pukul 12.00 hingga 02.00 WIB dengan pelayanan sebanyak dua sampai tiga pelanggan dalam sehari, mengindikasikan bahwa para korban melakukan pekerjaan dengan istilah "short time," yaitu melakukan layanan seks selama dua hingga enam jam (Irawan et al., 2019).

\section{SIMPULAN}

Setelah melakukan penelitian mengenai konstruksi wacana kekerasan seksual terhadap perempuan oleh media online Republika.co.id dengan menggunakan pendekatan analisis wacana model Roger Fowler dkk, peneliti menyimpulkan bahwa kasus kekerasan seksual di ROL dikonstruksi dengan praktik penggunaan bahasa yang belum berpihak kepada perempuan sebagai korban. Hal ini ditandai dengan marginalisasi posisi perempuan yang dominan dalam pemberitaan baik dari segi penamaan maupun penggambaran peristiwa kekerasan seksual. Marginalisasi tersebut tergambar dalam bentuk, pertama, penulisan kalimat yang pasif, sehingga posisi pelaku disembunyikan bahkan dihilangkan dari struktur kalimat. Kedua, mengasosiasikan perilaku pelaku dengan sesuatu hal, sehingga tindakan yang dilakukan seolah memperoleh dasar pembenaran. Ketiga, penggunaan eufemisme untuk memperhalus realitas mengenai kekerasan seksual yang menimpa korban, seperti pencabulan yang diganti dengan pelecehan dan persetubuhan. Keempat, penamaan tidak mandiri yang disematkan pada 
perempuan serta mengungkap identitas korban. Kelima, menampilkan replika kekerasan pada kasus pencabulan. Keenam, penulisan kalimat dalam bentuk nominalisasi, sehingga peran aktor sebagai pelaku diturunkan dalam sebuah peristiwa.

Berdasarkan temuan pada tiap-tiap berita yang dianalisa melalui dimensi analisis wacana model Roger Fowler dkk, dari sepuluh, hanya satu berita yang benar-benar berperspektif terhadap perempuan sebagai korban, baik dari segi pemilihan kosakata untuk menamai aktor yang terlibat, yakni korban dan pelaku, serta penggunaan tata bahasa berdasarkan model sintagmatik dan transformasi yang menampilkan pelaku sebagai pihak yang menyimpang atas permasalahan kekerasan seksual yang terjadi. Pada 10 berita yang dianalisis selama periode 23 November 2020 hingga 10 Maret 2021, jumlah korban terbanyak dialami oleh anak perempuan di bawah umur, yaitu kategori batas usia delapan belas tahun. Berdasarkan hasil analisis tersebut, pekerja media, yakni wartawan harulah memiliki perspektif gender, terkhusus ketika memberitakan kasus kekerasan seksual, sehingga posisi perempuan tidak lagi subordinat tetapi ordinat. Mengingat banyaknya strategi pewacanaan yang digunakan oleh media massa dewasa ini, pembaca sebaiknya memilah informasi secara teliti.

\section{DAFTAR PUSTAKA}

Chandradewi, A. A. S. D., Suandi, I. N., \& Artika, I. W. (2014). Pemberitaan kasus korupsi di Bali pada media cetak Bali Post dan Jawa Pos: suatu kajian teori Roger Fowle, Dkk. Jurnal Pendidikan Bahasa Dan Sastra Indonesia Undiksha, 2(1). Diakses dari https:// ejournal.undiksha.ac.id/index.php/JJPBS/article/view/3038

Dewan Pers. (2017). Buku saku wartawan. Jakarta: Dewan Pers.

Dharma,A.D. S.(2015). Keberagaman pengaturan batas usia dewasa seseorang untuk melakukan perbuatan hukum dalam peraturan perundang-undangan di Indonesia. Repertorium, 2(2), 168-176. Diakses dari https://www.neliti.com/id/publications/213158/keberagamanpengaturan-batas-usia-dewasa-seseorang-untuk-melakukan-perbuatan-huk

Eriyanto. (2011). Analisis wacana: pengantar analisis teks media. Yogyakarta: LKiS.

Fathurizki, A., \& Malau, R. M. U. (2018). Pornografi dalam film: analisis resepsi film "Men, Women \& Children." ProTVF, 2(1), 19-35. https://doi.org/10.24198/ptvf.v2i1.11347

Fernandez, P. W. (2013). Komodifikasi perempuan dalam iklan televisi. Jurnal ILMU KOMUNIKASI, 8(1), 60-80. https://doi.org/10.24002/jik.v8i1.182

Gangga, M. I. (2018). Pembingkaian berita media online pada Kompas.com dan Detik.com (pemberitaan konflik Antasari Azhar dan Susilo Bambang Yudhoyono periode FebruariMaret 2017). KINESIK, 5(2), 51-67. Diakses dari https://jurnal.fisip.untad.ac.id /index. $\mathrm{php} / \mathrm{kinesik/article/view/99}$

Hutahaean, B. (2013). Penerapan sanksi pidana bagi pelaku tindak pidana anak. Jurnal Yudisial, 6(1), 64-79. Diakses dari https://jurnal.komisiyudisial.go.id/index.php/jy/ article/view/119

Irawan, F., Gultom, I., \& Amsani, H. (2019). Media sosial dalam jaringan prostitusi mahasiswa di kota Medan. Jurnal Antropologi Sumatera, 17(2), 89-95. Diakses dari https://jurnal. unimed.ac.id/2012/index.php/jas/article/view/22493

Jaya, W., \& Basri. (2014). Hubungan patron - klien antara germo dan PSK (studi kasus Perumahan Jondul Lama Kelurahan Rejosari Kecamatan Tenayan Raya Pekanbaru). Jom FISIP, 1(2), 1-14. Diakses dari https://jom.unri.ac.id/index.php/JOMFSIP/article/ view/3124

Komnas Perempuan. (2014). 15 bentuk kekerasan seksual: sebuah pengenalan. Diakses dari komnasperempuan.go.id website: https://komnasperempuan.go.id/instrumen-modul- 
Volume 05 Nomor 02 Tahun 2022

DOI: $10.24198 /$ jkj.v5i2.36524

referensi-pemantauan-detail/15-bentuk-kekerasan-seksual-sebuah-pengenalan

Malik, A. (2019). Prostitusi online dan komodifikasi tubuh. Lontar : Jurnal Ilmu Komunikasi, 7(1), 1-8. Diakses dari https://e-jurnal.lppmunsera.org/index.php/LONTAR/article/ view/1562

MaPPI FHUI. (2018). Serba serbi kekerasan seksual terhadap perempuan. Diakses dari mappifhui.org website: http://mappifhui.org/2018/10/30/serba-serbi-kekerasan-seksualterhadap-perempuan/

Ngawiardi. (2016). Kajian kriminologi terhadap kejahatan pencabulan anak di bawah umur di Parigi Moutong. Legal Opinion, 4(4), 1-15. Diakses dari https://www.neliti.com/ $\mathrm{id} /$ publications/145804/kajian-kriminologi-terhadap-kejahatan-pencabulan-anak-dibawah-umur-di-parigi-mo\#cite

Pranawati, S. Y., Ginanjar, A. S., Matindas, R. W., \& Irwanto. (2020). Kerentanan remaja perempuan korban eksploitasi seksual komersial di Bandung. Sosio Konsepsia, 9(2), 198-212. https://doi.org/10.33007/ska.v9i2.1868

Prasetyo, R. A. (2018). Pedophilia (ditinjau dari aspek pelaku, kriminalitas dan perlindungan anak). Jurnal Harkat: Media Komunikasi Gender, 14(2), 121-128. https://doi. org/10.15408/harkat.v14i2.12814

Pratiwi, A. M. (2020). Kekerasan terhadap perempuan meningkat delapan kali lipat selama 12 tahun terakhir. Diakses dari jurnalperempuan.org website: https://www.jurnalperempuan. org/warta-feminis/kekerasan-terhadap-perempuan-meningkat-delapan-kali-lipatselama-12-tahun-terakhir

Rahmaniar, Amir, J., Jufri, \& Thaba, A. (2021). Representasi ideologi dan kekuasaan teks berita virus Corona di Indonesia (analisis wacana kritis Roger Fowler, dkk). Jurnal Pendidikan Bahasa Dan Sastra Indonesia Undiksha, 6(2), 76-81. Diakses dari https:// journal.stkipsingkawang.ac.id/index.php/JP-BSI/article /view/2324

Republika. (2018). Jejak Republika.co.id. Diakses dari republika.co.id website: https://www. republika.co.id/page/anniversary

Republika. (2020). Remaja di Tasikmalaya hamili anak di bawah umur. Diakses dari republika. co.id website: https://www.republika.co.id/berita/qkr5ws396/remaja-di-tasikmalayahamili-anak-di-bawah-umur

Republika. (2021a). Cabuli balita 4 tahun, polisi: pelaku bisa dijerat PP kebiri kimia. Diakses dari republika.co.id website: https://repjabar.republika.co.id/berita/qmf4so10022000/ cabuli-balita-4-tahun-polisi-pelaku-bisa-dijerat-pp-kebiri-kimia

Republika. (2021b). Istri komedian Isa Bajaj jadi korban pelecehan seksual. Diakses dari republika.co.id website: https://www.republika.co.id/berita/qn445u383/istri-komedianisa-bajaj-jadi-korban-pelecehan-seksual

Republika. (2021c). Polisi tangkap remaja cabuli anak 15 tahun di Deli Serdang. Diakses dari republika.co.id website: https://www.republika.co.id/berita/qnuzli349/polisi-tangkapremaja-cabuli-anak-15-tahun-di-deli-serdang

Romli, A. S. M. (2012). Jurnalistik online: panduan mengelola media online. Bandung: Nuansa Cendekia.

Satriya, B. (2011). Anak membutuhkan penegak hukum humanis (analisis putusan MK nomor 1/ PUU-VIII/2010). Jurnal Konstitusi, 8(5), 651-673. Diakses dari https:/jurnalkonstitusi. mkri.id/index.php/jk/article/view/185

Setiawan, D., \& Farida. (2020). Analisis wacana pelecehan seksual terhadap pekerja perempuan pada situs Never Okay Project. Soetomo Communication and Humanities, 1(2), 97-108. Diakses dari https://ejournal.unitomo.ac.id/index.php/sch/article/view/3111 
192 | Kajian Jurnalisme

Volume 05 Nomor 02 Tahun 2022

DOI: $10.24198 / \mathrm{jkj} . v 5 \mathrm{i} 2.36524$

Taufik, A. N. I., \& Syamsudduha. (2021). Penggunaan eufemisme dalam teks berita pelecehan seksual Tribun-Timur.com. Titik Dua: Jurnal Pembelajaran Bahasa Dan Sastra Indonesia, 1(1), 52-73. Diakses dari https://ojs.unm.ac.id/titikdua/article/view/23904

Valerisha, A. (2016). Dampak praktik konglomerasi media terhadap pencapaian konsolidasi demokrasi di Indonesia. Jurnal Ilmiah Hubungan Internasional, 12(1), 17. https://doi. org/10.26593/jihi.v12i1.2546.15-32

Yanto, O. (2015). Prostitusi sebagai kejahatan terhadap eksploitasi anak yang bersifat ilegal dan melawan hak asasi manusia (the prostitution as the crime concerning exploitation of the children and against human rights). Jurnal Legislasi Indonesia, 12(4), 1-18. Diakses dari https://e-jurnal.peraturan.go.id/index.php/jli/article/view/420

Yunastian, N., Pujiyono, \& Purwoto. (2017). Aspek hukum pidana membujuk anak melakukan persetubuhan (studi kasus putusan PN BANYUMAS Nomor74/Pid.Sus/2013/PN Bms Tahun 2013). Diponegoro Law Journal, 6(2), 1-13. Diakses dari https://ejournal3.undip. ac.id/index.php/dlr/article/view/19606

Zamzuardi, Y., \& Syahrul. (2019). Analisis wacana kasus pelecehan seksual terhadap perempuan pada berita online dalam perspektif analisis Sara Mils. Dialektika: Jurnal Bahasa, Sastra, Dan Pendidikan Bahasa Dan Sastra Indonesia, 6(1), 36-53. https://doi. org/10.15408/dialektika.v6i1.9750 